\title{
PENGAMBILAN KEPUTUSAN TENTANG PENATALAKSANAAN SINDROM PREMENOPAUSE PADA WANITA
}

\author{
CHINDY MARIA ORIZANI \\ AKADEMI KEPERAWATAN ADI HUSADA SURABAYA \\ chindyorizani@yahoo.com
}

\begin{abstract}
ABSTRAK
Wanita berhak memilih penanganan premenopause namun penentuan keputusan menimbulkan masalah baru. Penelitian ini bertujuan untuk menelaah literature mengenai pengalaman penentuan keputusan dalam memilih penanganan gejala menopause dan peran petugas kesehatan terutama perawat untuk membantu proses penentuan keputusan. Sumber diambil dari database PubMed, ScienceDirect, dan SAGEPub. Enam kata kunci yang digunakan adalah fulltext, berbahasa Inggris, penelitian kualitatif berhubungan dengan penentuan keputusan dalam memilih penanganan gejala menopause. Total terdapat 42 artikel dari empat Negara yang berbeda dan setelah dilakukan pemilihan kriteria inklusi, empat artikel yang ditelaah. Dari empat artikel menemukan bahwa wanita mengungkapkan perasaan mereka tentang kurangnya informasi tentang menopause dan manajemen gejala menopause sehingga mereka menemukan kesulitan ketika memutuskan untuk terapi. Sebagian besar itu menunjukkan tentang kurangnya dukungan dari petugas kesehatan. Dari artikel juga menemukan mengenai faktor tentang pengambilan keputusan, dibagi menjadi empat kategori: (1) karakteristik individu (demografi, pengalaman menopause, gejala); (2) nilai-nilai, sikap, keyakinan, dan preferensi (sikap dan keyakinan tentang menopause dan perawatan, modalitas disukai, toleransi untuk risiko / efek samping); (3) fakta dan informasi tentang menopause dan manajemen gejala (jumlah, jenis, sumber, kredibilitas, ketersediaan); dan (4) konteks pelayanan kesehatan (perawatan kesehatan penyedia komunikasi, kepercayaan, ketersediaan / waktu, pengetahuan, hubungan). Sebuah model yang komprehensif pengambilan keputusan manajemen gejala menopause harus dibuat di Indonesia. Perawat sebagai penyedia layanan harus meningkatkan kemampuan komunikasi yang efektif untuk membantu perempuan dalam proses pengambilan keputusan misalnya dengan menggunakan intervensi Coacing Decision di acara bimbingan atau konsultasi.
\end{abstract}

Kata kunci: penentuan keputusan wanita menopause, penetuan keputusan, peran perawat

\section{ABSTRACT}

Women have a right for choose the best premenopause treatment for her ownself, but decision making process sometime become new problem. Aim of this study was to review the literature regarding experience related to women's menopausal symptoms management decision making and role of care provider especially nurse for helping client in decision making process. Reference lists collected from PubMed, ScienceDirect, and SAGEPUb database. There are six keywords have been used for searching the article. Full-text, English language, qualitative study articles related to women's menopausal symptom management decision making were reviewed. A total of 42 articles from four different countries and after considered inclusion criteria, four articles were reviewed. From four articles found that women expressed their feeling about a lack menopause information and its menopausal symptom management so they found difficulties when decided for the therapy. Most of it showed about a lack of support from care provider. From articles also found about factors about decision making, devided to four catagories: (1) individual characteristics (demographics, menopause experience, symptomatology); (2) values, attitudes, beliefs, and preferences (attitudes and beliefs about menopause and treatments, preferred modalities, tolerance for risks/side effects); (3) facts and information about menopause and symptom management (amount, type, source, credibility, availability); and (4) health care context (health care provider communication, trust, availability/time, knowledge, relationship). A 
comprehensive model of menopausal symptom management decision making should be made in Indonesia. Nurse as a care provider must increase an effective communication ability to help women in decision making process for example by using Decision Coacing Intervention at tutoring or consultation event.

Keywords: woman's menopause decision making, decision making, role of nurse

\section{PENDAHULUAN}

Penentuan keputusan dalam pemilihan penatalaksanaan atau terapi baik hormonal maupun psikososial bagi wanita yang mengalami sindrom menopause yang tepat tidak hanya ditentukan oleh dokter atau perawat namun merupakan hak bagi klien dalam penentuan keputusan terapi yang akan digunakan. Klien berhak untuk mendapatkan informasi yang lebih baik mengenai perubahan menopause yang dialaminya, mengetahui strategi untuk menurunkan resiko atau dampak saat terjadi perubahan, menjaga kesehatan dan mengetahui serta berhak menentukan terapi yang sesuai dalam mengatasi masalah tersebut. Kemajuan teknologi kesehatan dan perkembangan dunia farmasi memproduksi berbagai jenis obat terapi hormonal membuat para wanita mengalami kebingungan dalam menentukan terapi mana yang akan dipilih. Dengan kondisi yang muncul para care provider kemudian dituntut untuk meningkatkan kepedulian terhadap nasib para wanita dalam proses penentuan keputusan tersebut. Strategi yang dilakukan oleh care provider antara lain adalah memberikan informasi yang terkait terapi, dukungan psikososial dalam menghadapi perubahan baik fisiologis maupun mental yang dialami oleh klien saat sindrom menopause terjadi.

Literature review dilakukan terhadap jurnal penelitian dengan topik pengalaman wanita yang mengalami menopause untuk menentukan keputusan dalam memilih terapi bagi gejala yang dialami baik berupa penelitian kualitatif dan peran perawat dalam mendukung penentuan keputusan tersebut. Tujuan literature review ini diharapkan mampu meningkatkan awareness perawat sebagai care provider terhadap pemenuhan kebutuhan informasi, konsultasi, edukasi bagi wanita yang mengalami sindrom menopause di Indonesia.

\section{METODE}

Strategi pencarian studi berbahasa Inggris yang relevan dengan topik yang telah ditentukan sebelumnya, dilakukan dengan mengakses database PubMed, ScienceDirect, dan SAGEPub dibatasi dari Januari 2006 sampai dengan Mei 2015. Keyword yang digunakan adalah "woman menopause", "woman menopause decision", "woman's decision making", "woman's menopause decision making", "nurse helps menopause woman", "nurse helps woman's decision making”. Artikel fulltext dan abstrak direview, untuk memilih studi yang sesuai dengan kriteria. Kriteria inklusi pada review ini adalah berbagai faktor yang mempengaruhi pengambilan keputusan, desain penelitian berupa kualitatif, bentuk bantuan dan penyedia bantuan dalam mengambil keputusan. Hasil pencarian tersebut ditemukan 42 artikel, setelah dilakukan analisis sederhana terhadap judul dan abstrak hanya empat artikel yang sesuai dengan kriteria inklusi.

\section{HASIL}

Penelitian yang ditelaah dalam literature review ini menggunakan penelitian kualitatif untuk mengetahui pengalaman wanita yang mengalami menopause untuk menentukan keputusan dalam memilih terapi bagi gejala yang dialami dan bentuk dukungan yang diberikan oleh care provider dalam membantu para perempuan dalam menentukan keputusan yang akan diambil. Penjelasan dari masing-masing hasil penelitian yang telah dikumpulkan adalah sebagai berikut:

Penelitian oleh Fiona M. Walter, et al (2004) berupa studi kualitatif dengan menggunakan focus groups discussion (FGD) dan wawancara semi-struktur untuk mengeksplorasi perspektif keefektifan 
komunikasi dan penentuan keputusan setelah berkonsultasi tentang menopause dan terapi hormonal. Dalam penelitan terdapat 40 partisipan yang diambil yang dibagi menjadi dua yaitu, 36 sampel dalam enam grup sedangkan empat orang untuk diwawancarai. Isi materi dalam FGD maupun wawancara membahas tentang faktor yang mempengaruhi komunikasi yang terjalin antara perawat dan klien saat berdiskusi tentang resiko dan keuntungan saat terjadi menopause dan pemilihan Hormonal Replacement Therapy (HRT), yang kedua adalah faktor yang mempengaruhi penentuan keputusan para wanita dalam menghadapi menopause dan pemilihan HRT atau terapi lainnya. Hasil dari penelitian ini menunjukkan bahwa sebagian besar partisipan mengharapkan bahwa komunikasi tentang resiko dan keuntungan dalam memfasilitasi pengambilan keputusan lebih lengkap dan penyedia fasilitas (barrier) lebih optimal dalam bertindak sebagai konsultan. Sebagian juga berharap agar dilakukan pendekatan secara langsung tiap pasien dan seorang konsultan harus meningkatkan ketrampilan dalam komunikasi dalam mengevaluasi kebutuhan pasien setiap kali datang untuk berkonsultasi. Partisipan berharap saat konsultasi disediakan materi berupa video, booklet, dll agar mempermudah bagi klien menerima penjelasan berdasarkan bukti yang terpercaya dan mempermudah klien menentukan pilihannya. Kelemahan dari penelitian ini tidak disebutkan secara jelas berbagai faktor yang mempengaruhi decision making.

Penelitian oleh Rosemary Theroux (2009) berupa studi kualitatif dengan menggunakan wawancara semi-struktur pad 21 wanita yang datang dan berkonsultasi pada nurse practitioners dan tujuan dari penelitian ini adalah mendeskripsikan pengalaman wanita selama menentukan keputusan pemilihan terapi hormonal maupun non-hormonal dalam menghadapi perubahan saat menopause. Berbeda dengan penelitian I, dalam penelitian ini disebutkan beberapa faktor internal maupun ekternal yang mempengaruhi partisipan dalam menentukan keputusan dalam menggunakan HRT antara lain keparahan dari sindrom klimaterium yang dialami, respon emosional, persepsi tentang quality of life, belief tentang penatalaksanaan, pengetahuan, harapan pada HRT, dukungan keluarga, media informasi, peran health care provider, dll. Dalam penelitian juga disebutkan ekspektasi pasien saat melakukan kunjungan dan konsultasi pada perawat yang tidak disebutkan secara detail pada penelitian I. Secara jelas juga disebutkan tentang peran nurse practitioner antara lain memberikan informasi secara lengkap hingga membantu penentuan keputusan. Dan penelitian ini memiliki kualitas yang lebih baik karena mencantumkan literature review, kelemahan studi, dan rekomendasi untuk penelitian berikutnya. Namun dalam penelitian ini tidak dijelaskan secara detail karakteristik dari partisipan.

Penelitian France Legare, et al (2007) melaksanakan penelitian dengan tujuan untuk mengidentifikasi kebutuhan dalam menentukan keputusan penggunaan natural health products (NHPs) saat menopause dan mengembangkan bantuan dalam pengambilan keputusan tersebut. Sama dengan penelitian sebelumnya desain penelitian yang digunakan adalah studi kualitatif dengan menggunakan FGD, wawancara dengan informan kunci dan konsultasi grup. Konten kemudian dianalisis dengan Ottawa Decision Support Framework (ODSF). Sama dengan penelitian sebelumnya peneliti membagi partisipan menjadi beberapa kelompok. Kelebihan dari penelitian ini tidak hanya melibatkan pasien, dokter dan perawat saja namun melibatkan beberapa ahli di bidangnya, antara lain farmasis, penentu kebijakan, advokat perempuan, pemilik toko NHP, dll. Kelebihan kedua adalah dalam penelitian disebutkan secara jelas karakteristik dari responden, karakteristik dukungan yang diharapkan oleh pasien (antara lain: dukungan lebih dari informan, penambahan sesi edukasi, jaminan insuransi, dll), disebutkan juga resiko penggunaan dari NHPs yang belum diteliti sebelumnya. Yang ketiga metode yang 
digunakan dalam analisis konten (metode ODSF) sangat komprehensif meliputi beberapa tahap antara lain: pengkajian faktor penentu keputusan, identifikasi kebutuhan dalam penentuan keputusan dan evaluasi kualitas serta kemajuan dalam penentuan keputusan. Ketiga kelebihan ini tidak ditemukan dalam penelitian I dan II, walaupun penelitian III memiliki perbedaan dalam hal intervensi berupa penggunaan NHPs bukan HRT. Kelemahan penelitian III adalah tidak disebutkan peran care provider dalam membantu klien dalam menentukan keputusan yang seperti disebutkan dalam penelitian II dan hanya menjabarkan kurangnya peran care provider.

Penelitian Ann Alfred, et al (2006) adalah sebuah penelitian kualitatif dengan pendekatan fenomenologi yang bertujuan mengekplorasi pengalaman wanita saat menghadapi menopause dan proses penuaan, terapi menopause, dampak dari penentuan keputusan, informasi lain yang terkait dengan menopause. Penelitian ini lebih terfokus pada pengalaman klien dalam menghadapi menopause yang meliputi faktor sosiokultural, kondisi tubuh saat menopause, respon stress wanita, skeptisme dari terapi, sumber yang membantu dalam menentukan keputusan, dll namun tidak meneliti tentang peran care provider sehingga penelitian I, II, dan III lebih detail sehingga rekomendasi hanya dari satu sisi yaitu sisi klien pengguna fasilitas kesehatan. Telaah beberapa penelitian diatas terdapat keterkaitan yaitu sebuah perilaku yang berfokus pada kebutuhan klien yaitu peran klien dalam menentukan keputusan pemilihan program yang sesuai dengan health belief masing-masing individu dan peran dari health care provider. Perspektif klien menjadi pertimbangan utama dimana pertimbangan tersebut dipengaruhi oleh beberapa faktor baik internal maupun ekternal termasuk didalamnya (1) karakteristik masing-masing individu, (2) nilai, perilaku, kepercayaan dan pentingnya quality of life tiap individu, (3) informasi dan fakta yang ditemukan oleh klien melalui media apapun, dan (4) bentuk dukungan atau peran health care provider/perawat dalam membantu pemenuhan kebutuhan klien. Dua dari empat penelitian diatas menyebutkan ketidakpuasan pada health care provider karena dinilai kurang optimal dalam memberikan informasi terkait menopause dan penatalaksanaannya sehingga pada poin implikasi terhadap keperawatan akan dibahas pentingnya peran perawat dalam membantu klien menentukan langkah yang tepat dalam memutuskan pilihan terapi saat menghadapi menopause. Beberapa penelitian yang telah ditelaah dalam artikel ini menunjukkan bahwa seluruh partisipan mengharapkan peran dari perawat berupa dukungan informasi terkait menopause dan membantu klien menentukan pilihan terapi menopause apa yang sesuai dengan kondisi tubuhnya. Karena sebagian wanita menyatakan kurang mendapatkan informasi yang tepat mengenai cara menghadapi perubahan baik fisik maupun psikis yang dialaminya sehingga klien malah merasakan efek negatif dan sindrom klimaterium misalnya distress akibat perubahan ketika berkonsultasi dengan care provider yang kurang komunikatif. Sedangkan pada sistem pelayanan modern, customer dalam hal ini adalah wanita menjelang menopause berhak menentukan tindakan yang akan klien jalani, oleh sebab itu peran perawat adalah menjembatani informasi dan keputusan yang akan diambil. Dalam Legare, et al (2008), terdapat tindakan berupa Decision Coaching yang bertujuan untuk memberikan dukungan untuk meningkatkan mutu penentuan keputusan yang terbaik dengan melibatkan klien itu sendiri dalam proses penentuan keputusan. Keterlibatan ini meliputi seberapa kebingungan klien saat menentukan keputusan, pengetahuan yang kurang pada klien tentang kondisinya, nilai dan dukungan klien dan seberapa besar klien ingin dibantu. Di Indonesia, upaya pencegahan maupun tindakan care terhadap wanita menjelang menopause ini masih kurang padahal merupakan lahan yang sangat baik untuk diteliti maupun untuk dilakukan sebagai sebuah program kesehatan, sedangkan para wanita ingin mendapatkan informasi lebih untuk dapat 
memahami perubahan dalam hidup mereka dan tentunya ketika perubahan tersebut menimbulkan pengalaman yang menyenangkan dalam hidup mereka maka quality of life akan meningkat sehingga wanita menopause masih tetap produktif untuk menghasilkan karya yang berguna bagi keluarganya. Langkah yang paling nyata adalah memperbanyak dilakukan penyuluhan terhadap wanita tentang menopause dan terapi mengadapi masalah sindrom klimaterium serta meningkatkan kualitas kemampuan komunikasi perawat sehingga mampu menyampaikan informasi yang tepat dan sebagai educator yang handal.

\section{KESIMPULAN}

Dari hasil telaah pada keempat penelitian ini penulis menyimpulkan bahwa klien berhak menentukan tindakan yang akan dipilih untuk menghadapi sebuah perubahan yaitu masa menopause dimana dalam proses penentuan keputusan tersebut klien tidak hanya sendiri namun akan mendapatkan dukungan berupa informasi yang tepat tentang perjalanan yang akan dialami serta tindakan apa yang sesuai dengan kondisi yang dialaminya. Metode yang digunakan berupa Decision Coaching yaitu membantu klien terlibat dalam menentukan keputusan. Peran perawat tersebut bisa dalam bentuk program penyuluhan maupun konsultasi langsung dengan klien. Sehingga tujuan akhir dari program ini adalah meningkatkan keterlibatan klien dan meningkatkan quality of life dari wanita menopause.

Namun masih terdapat kelemahan dari literature review ini yaitu seluruh penelitian yang ditelaah berasal dari sumber luar negeri seperti Amerika Serikat, Kanada dan Australia sehingga akan mengalami kesulitan dalam mencari evidence yang sesuai dengan karakter wanita Indonesia walaupun memang di Indonesia secara tidak langsung kegiatan decision making untuk pemilihan terapi sudah dilakukan namun sistem pelayanannya perlu diperbaiki.

\section{SARAN}
1. Perawat perlu meningkatkan

kemampuan dalam berkomunikasi yang efektif dalam membantu pemenuhan kebutuhan klien.

2. Perlu dilakukan penelitian dengan tema yang sejenis di Indonesa terutama tentang Decision Coaching terhadap penentuan keputusan yang diambil oleh wanita dalam menghadapi masa menopause.

3. Perlu dibentuk program kesehatan yang berfokus pada wanita menjelang menopause misalnya penyuluhan menopause dan konsultan kesehatan wanita.

\section{DAFTAR PUSTAKA}

1. Alfred A, et al. 2006. Women's decision making at menopause - a focus group study. PubMed: Aust Fam Physician 2006;35:270-2

2. Gaffar. 1999. Pengantar Keperawatan Profesional. Jakarta: EGC

3. Larrabee, J.H. 2009. Nurse to Nurse: Evidence-Based Nursing. West Virginia: The McGraw-Hill Companies, Inc

4. Légaré F, et al. 2007. Women's decision making about the use of natural health products at menopause: a needs assessment and patient decision aid. ScienceDirect: J Altern Complement Med 2007;13:741-9

5. Mangoenprasodjo. 2004. Siapa Takut Menopause: Kiat Memasuki Waktu Paruh Baya Tanpa Rasa Was-was dan Cemas. Yogyakarta: ThinkFresh

6. McKenna. 1999. Evidence-based practice: demolishing some myths. Nursing Standard. 14, 16, 39-42. Date of acceptance: November 151999

7. Mustafa, et al. 2012. Perception and Experience Regarding Menopause among Menopaused Women Attending Teaching Hospitals in Erbil City. Global Journal of Health Science. 4:3:170-178

8. Nacar, et al. 2008. Perceptions and Attitudes Toward the Menopause: A Study from Kayseri. Turkish Journal of Public Health. 6: 2: 36-45

9. Nosek, et al. 2008. Silence, Stigma, and Shame: A Postmodern Analysis of 
Distress During Menopause. Advances in Nursing Science. 33: 3: 24-36

10. Nusrat, et al. 2008. Knowledge, Attitude and Experience of Menopause. J Ayub Med Coll Abbottabad. 20: 1: 56-59

11. Ospina, S. 2004. Qualitative Research. SAGE Publications.

12. Polit \& Beck. 2003. Nursing Research: Principles and Methods. 7th Edition. Lippincott Williams \& Wilkins

13. The Women's Health Council. 2008. Women's Experiences and Understandings of Menopause. Dublin: The Women's Health Council

14. Theroux. 2010. Women's Decision Making During the Menopause Transition. SagePub: Journal of the American Academy of Nurse Practitioners. 22:612- 621

15. Walter, et al. 2004. Women's views of optimal risk communication and decision making in general practice consultations about the menopause and hormone replacement therapy. ScienceDirect: Elsevier: Patien Education and Counceling 53:121-128

16. William, B. 2010. Evidence Based Nursing: The way to patient-centered care Nursing Management Volume 41 Number 10 Pages 10-12

17. Woods NF, et al. 2007. Impact of clinician and patient attitudes on clinical decision making for the symptomatic menopausal woman with or without comorbidity. Expert Rev Neurother 2007;7:S27-34 